\title{
Realism in Normative Political Theory
}

\author{
Enzo Rossi | University of Amsterdam \\ Matt Sleat | University of Sheffield
}

\begin{abstract}
This paper provides a critical overview of the realist current in contemporary political philosophy. We define political realism on the basis of its attempt to give varying degrees of autonomy to politics as a sphere of human activity, in large part through its exploration of the sources of normativity appropriate for the political, and so distinguish sharply between political realism and non-ideal theory. We then identify and discuss four key arguments advanced by political realists: from ideology, from the relationship of ethics to politics, from the priority of legitimacy over justice, and from the nature of political judgment. Next, we ask to what extent realism is a methodological approach as opposed to a substantive political position, and so discuss the relationship between realism and a few such positions. We close by pointing out the links between contemporary realism and the realist strand that runs through much of the history of Western political thought.
\end{abstract}

Much contemporary Anglo-American political philosophy operates as a branch of applied ethics: normative political theory is supposed to implement moral commitments external to politics, be they teleological ideals or deontological constraints. However in recent years-under the loose label of 'political realism'-an alternative approach has emerged, or perhaps reemerged (Galston 2010; Runciman 2012). Crudely, realists maintain that political philosophy should not seek to regiment politics through morality; rather, it should theorise about the distinctive forces that shape real politics. Critics of realism see this move as a capitulation of normative theory in favour of descriptive approaches to politics. Realists see it as a way to make political philosophy more relevant and less ideological.

This article has two main objectives and as many main sections. First, we propose a working definition of realism, and a critical overview of what we take to be the four key arguments in favour of that position. Second, we explore the status of realist theory: is it best characterised as a series of methodological concerns or does it represent a substantive political position it is own right? In the brief conclusion we discuss to what extent realism is (or could be) a new development rather than a revival of a traditional current of political thinking.

\section{What Is Political Realism?}

Realists reject what Bernard Williams dubs 'political moralism', or the 'ethics first' approach (Geuss 2008: 9), in both its variants: the 'enactment model' and the 'structural model' (2005: 1- 
3). ${ }^{1}$ The former consists in deriving political prescriptions from pre-political ethical ideals such as happiness, equality, or autonomy. The latter amounts to specifying the limits of permissible political conduct through pre-political moral commitments such as a Kantian notion of autonomy or some conception of moral rights. Those ethical values are pre-political in two senses: they are taken to float free from the forces of politics, and they are assigned a foundational role insofar as they have antecedent authority over the political and determine or exhaust the appropriate ends and limits of politics. Realists take issue with both of those claims.

Before considering the arguments for rejecting the moralist position, let us get clearer about what the realist alternative amounts to. As the negative characterisation above prefigures, insofar as realism is a normative theory (some realists have doubts about the sharpness of the normative/descriptive dichotomy: cf. Geuss 2008; Rossi 2010a) it can be distinguished on the basis of its choice of the relevant sources of political normativity. Broadly, realists maintain that political theory should begin (in a justificatory rather than temporal sense) not with the explication of moral ideals (of justice, freedom, rights, etc.) which are then taken to settle the questions of value and principle in the political realm but in a (typically interpretative) understanding of the practice of politics itself (Geuss 2008; Newey 2010; Rossi 2012; Sangiovanni 2008; Waldron 2013; Williams 2005). Mainstream moralist political philosophy fails, from the realist perspective, to take seriously enough the peculiarities of the political and in doing so is unable to appreciate the complexity of the causal and normative relationship between morality and politics. And to the extent to which politics can be theorised in a manner that is appropriately sensitive to the nature of politics, political philosophy ceases to be a branch of moral philosophy (Philp 2012: 631).

There are strong and weak variations of this central realist claim regarding the autonomy of the political. The strong version insists that it is possible to derive normative political judgments from specifically political values - a position resting on a subset of the view that not all values are moral values, plus the more controversial claim that such political values can and should guide politics, whereas moral values are ill-suited to that task (Geuss 2008). Whether and how either or both components of that claim can be sustained is an issue high on the agenda of realists (e.g. Rossi 2012; Sleat 2014) and of their critics. The controversy largely turns on whether moral normativity is eliminable from political philosophy (e.g. Hurka 2009; Erman and Möller 2013, but cf. Jubb and Rossi 2014; Larmore 2013, but Sleat 2014).

The weaker version of the realist claim accepts that there is a place for morality in politics but seeks, in Williams' words (2005: 3), to explicate 'an approach which gives greater autonomy to distinctively political thought'. On this view there is not such a stark contrast between politics and morality, and indeed morality may have a role to play in providing a source of political normativity, yet it remains important to appreciate the manner in which politics remains a distinct sphere of human activity, with its own concerns, pressures, ends, and constraints which cannot be reduced to ethics (nor law, economics, religion, etc.) (Philp 2007, 2012; Newey 2013; Sleat 2014; Sleat 2013; Waldron 1999).

This definition allows us to clarify the difference between realism and non-ideal theory. Realism is often construed in opposition to utopianism, and so it is taken to be characterised

${ }^{1}$ For more on the 'vice' of moralism see Coady (2008) and Taylor (2011) 
simply by a concern for issues of feasibility (e.g. Freeden 2012; Valentini 2012: 657-660; Zuolo 2012). Yet if the defining feature of realism is the attempt to give autonomy to the political and political theorising through a fuller understanding of the sources of normativity in politics, then the issue of feasibility turns out to be orthogonal to the realism/moralism dichotomy - which is not to say, though, that feasibility issues will not feature in some comprehensive realist accounts of politics, but they will not be exhaustive of them and will sit alongside a host of other considerations (such as those explored below). Furthermore, there is no reason to presume that specifically political values incorporate feasibility constraints any more than moral values do. ${ }^{2}$ Realist concerns with people's actual motivations, with the difficulties of collective action problems, and with the inevitability of (some) coercion have been misinterpreted as concerns about feasibility, whereas they are concerns about the modes of action most typical of politics, as opposed to other spheres of human action. Utopianism may even be better served by a realistic take on which values can be genuinely transformative and which ones are merely ideological (Geuss 2010; Owen 2010) — which isn't to say that realism cannot engender complacency towards the status quo (Finlayson 2014). Still, conceptually nothing precludes realists from resurrecting the 1968 slogan "Be realistic. Demand the impossible."

\section{Realist Themes}

We can now turn to what we take to be the four most important themes in contemporary realist thought, which will also help us delineate a wider picture of the realist position and of the fault lines between realism and mainstream political philosophy.

Ethics and politics - Realists posit a dichotomy between the realm of human action that is appropriately regulated by morality (or ethics —we use those terms interchangeably for now), and the realm of politics, which requires separate norms. The exact nature of this dichotomy depends on whether one endorses the more or less radical version of the autonomy of the political. But this move is not a stipulative land grab. It is motivated by presently unfashionable considerations that are familiar to political philosophers at least since Machiavelli, Hobbes, Schmitt, and Lenin, if not since Thucydides (Bolsinger 2001; Dyson 2005; Hawthorn 2014).

The broadly Hobbesian thought is that, if ethics could effectively regulate behaviour in political communities as it does among (say) friends and acquaintances, we would not require politics. We need politics in part precisely because of the ubiquity of moral disagreements about what we collectively should do, the ends to which political power should be put, and the moral principles and values that should underpin and regulate our shared political association. As such politics cannot be a domain that is straightforwardly regulated by morality. From that follows either the loosely Machiavellian claim that politics has its own normativity (or 'internal logic'), which floats free from personal morality and can be directly at odds with it, or the more complex

\footnotetext{
2 Perhaps the confusion between realism and non-ideal theory is partly due to the fact that most moralistic political philosophy is also ideal theory. But political moralism can feature in much the same way in non-ideal theory (e.g. Mason 2010 and, for a realist critique, Sleat 2012).
} 
yet less radical claim that politics cannot be exhausted by morality and that key political concepts such as legitimacy and authority need to be rethought in conditions of ineradicable moral and political disagreement (Philp 2012; Philp 2007).

This position has often been supplemented with some more general remarks regarding the relatively weak motivational force of morality (Geuss 2008: 9-11), and the need to supplement our understanding with a form of what Galston has called 'psychological or motivational realism' (2010: 398) which also gives due recognition to the role of interests, rhetoric, political leadership (Sabl 2002), appeals to history, and, maybe more controversially, the use of coercive force to generate desired human responses (Stears 2007). Critics of realism respond by arguing that observation of the weak motivational force of morality over politics does not warrant the abandonment of the 'ethics first' approach (Estlund 2011; Finlayson 2014). For realists that reply is off the mark: the point is not that morality is only weakly capable of directing politics, but that political moralism reduces political problems to matters of personal morality (see Williams' discussion of humanitarian intervention - 2008: ch. 12), leaving no space for the sort of concerns (e.g. order and stability) or features (e.g. conflict, interests, passions) that ensure politics cannot simply be 'applied moral philosophy'. Morality may be successful at causally influencing politics as any other grand aspiration (cf. Sleat 2013b), but that is not to say that it can purport to guide political behaviour in the same way in which it guides personal conduct nor that it always provides a suitable blueprint for action in a sphere that is constituted by disagreement, contestation, and coercion.

'Political Moralism' as ideology - Even those who endorse the more radical version of the autonomy claim do not deny that there is any connection between morality and politics. Echoing Nietzsche, Raymond Geuss takes the politics/ethics dichotomy in a more radical direction: "Ethics is usually dead politics: the hand of a victor in some past conflict reaching out to try to extend its grip to the present and the future. There is nothing inherently wrong with this." (2010: 42). That is a familiar point from the critical theory tradition. Crystallised power can pass itself for morality, and so even for a critique of power. Geuss makes just that point when he berates the ideological character of liberalism. ${ }^{3}$ Yet realists do not need Marxian leanings to worry about ideology (see Dunn 1990). Any realistic take on politics needs a theoretical device to distinguish between bona fide politics and other forms of structured coercion.

Bernard Williams notably distances himself from the mainstream (liberal) view that consensus should be the aim of politics, yet he does not give up on some justificatory standards for the exercise of political power (as we will see in more detail in the next sub-section), such as his 'critical theory principle': "...the acceptance of a justification does not count if the acceptance itself is produced by the coercive power which is supposedly being justified" (2005: 6. Also see Williams 2002: 225-232; Bavister-Gould 2013; Newey 2010: 462). Some commentators argue that the critical theory principle harbours moral commitments that take Williams too close to the mainstream approach he wants to reject insofar as it may implicitly invoke a moralised ideal of political consensus (Sleat 2010) — another issue which turns largely on whether distinctly political norms can be extracted from the very concept of politics (cf. Hall 2013a, Jubb

${ }^{3}$ Geuss (2002). On realism and the study of ideology see Humphrey (2012). 
forthcoming-a). And there remains a question as to exactly what constitutes forced acceptance, a concern exemplified by the fact that some realists insist that politics is the process through which agreement is forged, hence all political order must be an 'artefact' of politics itself and will necessitate some degree of coercion (Stears 2007).

The ideology critique aspect of realism also highlights another important point: archmoralists like G.A. Cohen (2008) ${ }^{4}$ make much of the claim that even Rawlsian constructivism is too tainted by its accommodation of some unpalatable facts about human motivation, but they rarely question the origins of the purportedly 'fact-insensitive' moral intuitions that ground their own normative position (Jubb forthcoming-b; Rossi 2014; Schwartzmann 2006).

Justice, legitimacy, and other political values - Political moralism has been characterised by an almost exclusive focus on justice, in no small part because of the influence that John Rawls' work (and the critical reactions by G.A. Cohen, Ronald Dworkin, and Robert Nozick) has had on the sub-discipline over the past several decades. Realists resist that focus by pointing out how the resources of Western political thought have far more to offer than a narrow focus on justice (Geuss 2008: 70-76), by demonstrating how the lens of justice distorts our grasp of other political problems (Ceva and Rossi 2012; Kukathas 2003, 2013), and by showing how the moralistic priority of justice yields an incomplete account of the scope of justice (Rossi 2012). Several realists also assert the primacy of legitimacy by stressing the extent to which reason does not lead to unanimity in moral or political matters and hence the creation and maintenance of a legitimate authority that can make binding collective decisions on such issues becomes of paramount concern (Larmore 2013; Sleat 2013; Waldron 1999). Politics must settle through authority and law what cannot be settled through reason or morality. There is hence a level of decisionism often associated with Hobbes and Schmitt, present in contemporary realism.

The most widely discussed realist attempt to shift the focus of political theory from justice to legitimacy, though, is Williams'. He points out how an (Hobbesian) understanding of the concept of politics reveals that the first political question concerns "the securing of order, protection, safety, trust, and the conditions of cooperation" (2005: 3). The question here is the central one for political theory: which political arrangements can solve the first political question and also satisfy the 'basic legitimation demand', i.e. find a solution to the first question that is somehow "acceptable" to those subject to it and hence legitimate. Williams' answer is contextor practice-dependent. ${ }^{5}$ Liberalism is appropriate "now and around here" where its central normative commitments 'make sense' as authoritative to those subject to them. The legitimation of political power is always a contextual question regarding what stands in need of justification, to whom, and what reasons are going to be normatively salient in those conditions (which will

\footnotetext{
${ }^{4}$ For a less controversial subset of that position see Estlund (2011). For a realist critique of Cohen's factinsensitivity see Hall (2013b), Jubb (2009) and Rossi (2014).

${ }^{5}$ On practice-dependence see Sangiovanni (2008), and for an application to realist legitimacy Rossi (2012). One may distinguish between practice-dependence and contextualism, or between different forms of practice dependence. Sangiovanni usefully distinguishes between 'cultural conventionalist' and 'institutionalist' practice-dependence. The difference lies in the sources of normativity: culturally constructed meanings of social goods for the former, interpretations of the value of existing institutions for the latter (2008: 138).
} 
likely include moral reasons but could also include considerations regarding, for instance, efficiency, tradition, and economic stability or growth).

As with the critical theory principle, this aspect of Williams' position has also attracted charges of covert moralism (Bavister-Gould 2013), or at least of excessive focus on something akin to consensus (Sleat 2010; Jubb forthcoming-a; but cf. Hall 2013a). It is worth pointing out, however, that perhaps some of Williams' critics tend to conflate the point that the motivation for Williams' realism can be found in his wider ethical philosophy (which he contrast with the narrowness of the moral), and whether the justification for specific elements of his realist theory of legitimacy rests on moral values (which is unlikely, given Williams' scepticism towards the 'peculiar institution' of morality).

Alongside those realists like Williams who seek to prioritise legitimacy as a fundamental political value once we accept that politics is primarily about providing authoritative order in conditions of conflict, there are others who are more sceptical. Geuss, for example, insists that

The beliefs that lie at the base of forms of legitimation are often as confused, potentially contradictory, incomplete, and pliable as anything else, and they can in principle be manipulated . . . they also do not have a coherence and independence of the wider social and political world that would allow one to treat them completely in abstraction (2008: 36).

For Geuss, and others (Sleat 2014; Sleat 2013a), the legitimation of political power cannot float totally free from the contestations of which politics consists, but are instead part of the very struggle for power that is fundamental to the political. Hence, and relating back to the previous theme of realism-as-ideological-critique, realism insists that political theorists recognise their own partisan and non-neutral status as interested agents in the real-world struggle for legitimation. (For further realist discussions of legitimacy see: Bavister-Gould 2013; Ermin and Möller 2013; Hall 2013a; Horton 2012; Larmore 2013; Mason 2010; Newey 2010; Rossi 2013; Rossi 2012; Sigwart 2013; Sleat 2011; Sleat 2010).

Alongside legitimacy, realists claim that there are further distinctly political values- order, stability, political freedom and equality, toleration etc.- - that should be the proper focus of political theorists' attention. Some, like Williams (2005) or Newey (2013), have sought to argue that such values are political because they cannot be completely reduced to a set of moral considerations but must instead be understood through the way in which they feature in our institutions and practices and the various roles that we require them to play in actual politics. Others have argued that these political values can be explicated and operationalised without the need to make any appeal to moral values or principles (Jubb and Rossi forthcoming) (this claim can be made more radical by insisting that such values exhaust normativity in politics, hence leaving no space for the moral in politics). This latter position does not require us to appeal to meta-values to know when to deploy political as opposed to moral values: politically relevant predicaments can be individuated by considering the very concept of politics, which we can individuate by contrasting it to raw domination on the one hand, and personal interactions on the other hand (Hall 2013a, but also cf. Sleat 2010). That is not to say that there are not grey 
areas between the ethical and the political. The distinction need not be sharp to be clear. And more importantly, the distinction does not imply that we can choose whether to enter politics. For most realists politics is a given: the first question isn't whether we should establish coercive political institutions, but rather how we should structure them. So there's a connection between realism and the tradition of political naturalism, namely the view-commonly associated with Aristotle- that the political condition is an essential part of human life (Newey 2013: 29; Rossi 2010a).

Political Judgement - We have now seen how realists, especially through their focus on legitimacy, tend to be committed to strongly contextual approaches to political normativity. Contextualism also provides a way into the last and so far least developed focal point of realism, namely the rejection of ambitious attempts to formulate grand theories from which to derive prescriptions for any possible political scenario and in reference to which we can judge political behaviour, in favour of a normativity that is appropriately sensitive to the specific conditions under which political decisions are taken and agents act (Geuss 2008, 8).

The link between realist accounts of political judgement and contextualism has been stressed primarily by scholars of the history of political thought, many of whom have sought to demonstrate the contingencies and conditionalities of politics by drawing attention to the diverse possibilities and constraints under which political actors acted in the past and the manner in which that affected their contemporaries and our own assessments of those actions(see Bourke and Geuss 2009; Dunn 2000; Dunn 1990; Sabl 2012; Schlosser 2014. For critical realist discussions of the relationship between history and political philosophy see Floyd and Stears 2011). But it can also be developed in a theoretical directions: if guiding politics is a matter of craft and virtue (or Machiavellian virtù — cf. Maloy 2013), one could ground scepticism towards overarching algorithmic moral principles in the virtue-ethical idea of virtues as goods internal to practices (Philp 2010; Philp 2007).

Discussions regarding the nature of political agency and judgement have often tended to focus on the extent to which political agents are subject to a set of pressures or pursue a series of ends that are unique to politics and which might require them to behave in ways that would otherwise be deemed morally dubious or indeed outright abhorrent. This disjunction could lead to a Machiavellianism in which politics is not subject to moral criteria but is judged by the extent to which political action realises its intended goals, and hence it would be wrong to pass ethical judgement on political actors (unless we take the criteria of success to be a form of political ethics). Yet most contemporary realists have tended to prefer a more complex Weberian approach to political judgement in which the ethical paradoxes of political action are brought to the fore, for instance, that the achievement of good ends may necessitate employing morally dubious means or that political agents must act despite the irreconcilable ethical tension between a concern for what is right ('the ethics of conviction') and the responsibility for the outcomes of one's actions ('the ethics of responsibility') (Weber 1994). Such ethical paradoxes may be fundamentally unresolvable and hence many realists have been led back to discussing the extent to which politics necessarily requires moral agents to 'get their hands dirty' by engaging in 
practices, such as lying (Newey 1997; Williams 2005: ch. 13) ${ }^{6}$ or the use of (legitimate) violence, that would in non-political scenarios be deemed highly objectionable (Bellamy 2010; Coady 2008; Philp 2010; Philp 2007). In a comparative perspective, even Gandhian non-violence has been read as a form of practical political orientation developed in response to a rather bleak picture of the circumstances of politics (Mantena 2012).

\section{The Politics of Political Realism}

While it is undoubtedly true that contemporary liberal theory has been the critical focus of the vast majority of the recent realist literature, it is important to stress that this has often centred on the very specific form of neo-Kantianism exemplified by the work of John Rawls (1996; 1999), Jurgen Habermas (1997), and their largely Anglo-American followers. There's nothing objectionable about this narrow focus, bearing in mind just how dominant this particular strand of liberal theorising has been over the past four decades. Furthermore, other theories such as comprehensive (e.g. Dworkin, 1990) or perfectionist (e.g. Raz, 1986; Chan, 2000) liberalism might without too much extension be liable to the same realist concerns regarding the over moralisation of politics. It's easy to think therefore, and especially because of the very general and critical tone in which some realist critiques of liberal theory have been couched (e.g. Geuss, 2008), that realism is inherently antithetical to liberalism. Yet there are some, including those who are sympathetic to realism, who have offered readings of Rawls' later work which emphasises its realistic credentials (Gledhill 2012; Jubb forthcoming-a; Rossi 2013), and the extent to which Rawls and his followers are guilty of the numerous moralist/idealist sins remains a matter of debate. Furthermore, liberalism is a diverse and complex tradition, and many contemporary realists have themselves been attracted to certain variations of liberal theory that are interpreted as more in keeping with the concerns of realism. These have included theories of agonistic (Gray 1995) or modus vivendi liberalisms (Horton, 2010; Gray 2000; McCabe 2010), accounts such as those offered by Bernard Williams (2005) inspired by Judith Shklar's influential 'liberalism of fear' (Shklar 1998. Though see Forrester 2012 for a critical discussion of the extent to which Shklar's work is consonant with contemporary realism), or attempts to rethink the fundamental normative commitments of liberalism in realist terms (Sleat 2013). Such theories present liberalism as a particular response to the characteristically realist political problem of order and stability.

This is not to deny that there are realists who reject liberal politics, most notably Raymond Geuss and Chantal Mouffe. Following Adorno, Geuss doesn't pair his critique with alternative proposals (2008: 96). The ubiquity of conflict leads Mouffe (2005) to endorse a radical version of agonistic democracy which rejects the liberal ambition to make politics a sphere of consensus and neutrality yet is able to tame the struggle for power between different hegemonic political positions to enable peaceful and stable co-existence. And Mouffe is not alone in turning to democratic politics as a response to permanent disagreement and conflict: Jeremy Waldron

\footnotetext{
${ }^{6}$ For an interesting discussion of the extent to which even political theorists may have a duty to lie see Jubb and Faik Kurtumulus (2012).
} 
(1999) and Andrew Mason (2010) argue that majoritarian democratic institutions enable humans to reach commonly binding, normatively authoritative decisions in conditions of ongoing political conflict. In presenting democracy in a realist light, such theories attempt to do justice to the openness and self-constitutive nature of politics while providing the procedural means through which collective action is made possible with the minimum of (contestable) normative commitments.

That recent realist theorists have endorsed and rejected liberalism, while others have favoured democratic designs, points to the fact that realism is itself politically indeterminate. This is true in the sense that realism is not itself a substantive political position (one is not a realist in the same way that you are a liberal, socialist, conservative, etc.), but also insofar as realism neither uniquely justifies any specific political project nor needs to be inherently more sceptical or dismissive of particular projects over any others. What we have are theories of politics that are more or less in keeping with realism's claims about the political. But beyond the engagements already mentioned, these explorations have yet to take place and should form part of the future realist research agenda.

A few pointers can be noted in advance of that work. It might seem that the realist emphasis on the need to fully appreciate the social context in which political action and judgements take place might align realism close to communitarian theories of politics. Yet communitarianism, though its political ramifications have always been contested, assumes the sort of cultural and value homogeneity that any realistic theory of politics cannot countenance (for a discussion of this see Williams 2005: ch. 3). Socialism might be thought of as inherently more realistic insofar as it not only takes seriously conflicts of interests but views these in terms of a nexus of power relations between economic groups. From a realist perspective, however, (and here its Weberian heritage is evident) this is a one-sided view of the conflicts that politics must address, which includes those of value and ideals which are distinct from and cannot be reduced to those of interests. Equally socialism might also assume a too harmonious account of human interests than is compatible with realism, as is evident in G. A. Cohen's politics-as-camping-trip thoughtexperiment (2009. For a realist critique of Cohen see Hall 2013b; Jubb forthcoming-a). Realism also cannot countenance any notion that politics proper might cease to be once all property is commonly owned (politics is a response to conflict, conflict is ubiquitous, therefore politics is a permanent and inevitable feature of human life), and this is a consequence of socialism's failure to give appropriate autonomy to the political by making it epiphenomenal to the economic. Likewise, fascism accepts the role of power, conflict and the irrational in politics yet simultaneously overplays the prevalence of pre-political social identities (e.g. Volk), while also, and especially in its Nazi manifestation, often has to rely upon the increasing use of violence, manipulation and secrecy to maintain its rule that is indicative of domination rather than politics (Philp 2007: 71-74). And conservatism might share a general scepticism about the role of rationalism in politics, and place greater emphasis on tradition, history, deference, the practical, etc., it too can often rely on an overly harmonious account of human life. Republicanism has a similar concern with regards to the dangers of arbitrary power, yet also relies upon too strong a notion of a common good.

So while realism is politically indeterminate, and in that sense not a substantive political position, it would be mistaken to characterise realist thought as simply a set of methodological 
concerns directed towards correcting any overly unrealistic political theory. A better way of characterising realism is as a family of theories of politics, one which competes with those of other political traditions only when they are too idealistic or moralistic, and in the context of which any sufficiently realistic substantive approach to politics (e.g. liberalism, socialism, conservatism, etc.) must situate itself. In fact, some realist elements are already present in mainstream political philosophy (e.g. practice-dependence and focus on institutions), yet they are often entangled with if not dwarfed by moralist elements (e.g. the priority of justice or the use of supposedly pre-political moral intuitions). Clarifying the incompatibility of those elements and recognising the force of realist claims should force a methodological transformation of the discipline: some theorists would embrace fully fledged political realism, others would maintain the moralist approach and so move away from political theory and towards moral philosophy.

\section{Conclusion: 'New' Realism?}

It is worth finishing by reflecting on the extent to which the resurgence of interest in political realism is 'new' (Honig and Stears 2011; Mulieri 2013) or whether it is continuous with the realist tradition in political theory or with realism as it features in international relations (IR) theory.

It is striking that the retrieval of realism in contemporary political theory took place with barely any acknowledgement that realist thought was not only present in its sister sub-discipline of IR theory but that it has long flourished as one of the most dominant and nuanced intellectual traditions. To those familiar with IR theory, the very idea that realism needed to be retrieved at all would look outlandish. Since then there has still been very little attempt to trace the nature of the relationship between these realisms.

One possible explanation of this disregard is the assumption that realism in IR is characterised by amoral or value neutral analysis that is obsessed with little other than the pursuit of national interests and power politics. This is realism as Realpolitik. And, as we have seen throughout this paper, political realism does not have the same ambition of providing a normatively neutral account of politics and political action. Yet while this characterisation might be true of the neo-realism most often associated with the work of Kenneth Walz (2010), it grossly mischaracterises the classical realists such as Hans J. Morgenthau, E. H. Carr, Reinhold Niebuhr and John Herz. Theirs are much more philosophically sophisticated analyses which are very clearly attuned to exactly the sort of concerns that have motivated the recent revival of political realism, most notably the complex relationship between ethics and politics, an appreciation of the political as a sphere of human activity that provides order in a context of disagreement but which cannot be reduced to morality, a scepticism towards the power of reason and morality in political life, and the difficulties inherent in judging political action. ${ }^{7}$ Despite the fact that these scholars dedicated their careers to exploring exactly these issues, and hence have deposited a very rich body of work, contemporary political realists have almost completely shunned any engagement with this classical realism (the only exceptions to this are

\footnotetext{
${ }^{7}$ Amongst the texts most relevant in this regard see: Carr 2001; Herz 1951; Morgenthau 1967; Morgenthau 1946; Niebuhr 2011; Niebuhr 2005)
} 
Bell 2009b; Scheuerman 2013; Sleat 2014; Sleat 2013a). As Scheuerman remarks (2013), however, this lack of awareness may come at the high-cost of unwittingly reproducing the sort of conceptual ambiguities that plagued these earlier contributions, of blindly treading already well worn-paths that lead to intellectual dead-ends, or, and more optimistically, denying themselves access to hard won and potentially fruitful insights or theoretical resources (leading them to reinvent the realist wheel).

There is little completely new about contemporary realism if viewed as part of a tradition of thought that goes back at least to Thucydides (or possibly Herodotus - see Schlosser 2014) and continues through Aristotle, Augustine, Machiavelli, Hobbes, Hume, Nietzsche, Schmitt, and Weber (leaving aside more canonically contentious and ideologically aligned theorists such as Burke or Lenin). Besides, many of the other canonical figures of Western political thought were more realistic than most contemporary political philosophers, insofar as they didn't aspire to construct purely normative theories grounded in pre-political moral commitments, but rather a blend of descriptive and normative elements anchored in an understanding of the specificity of the political. Contemporary realism might look new to a discipline in which the application of Kantian ethics (as opposed to Kant's political philosophy: cf. Ripstein 2009) has been so dominant for some four decades, along with other forms of moralism one may call neoBenthamite teleology and neo-Lockean jusnaturalism. But contemporary realism is thoroughly continuous with both the realist tradition generally and some of the specific concerns of IR realism (and, indeed, legal realism). ${ }^{8}$ If realism is to go beyond representing a mere anti-moralist gesture then the future research agenda of realist thought should include a certain amount of looking back to previous iterations of political realism both to better understand its own theoretical heritage but also to allow it to draw upon the intellectual resources and lessons (successes and failures) of previous realist thinkers (see Sabl 2012; Scheuerman 2013; Whelan 2004). And at least part of what we hope to have offered here is a series of reasons for thinking that such an endeavour might be worth undertaking.

\section{References}

Bavister-Gould, Alex. 'Bernard Williams: Political Realism and the Limits of Legitimacy.' European Journal of Philosophy 21.4 (2013): 593-610.

Bell, Duncan (ed.). Political Thought and International Relations - Variations on a Realist Theme. Oxford: Oxford University Press, 2009a.

Bell, Duncan. 'Under an Empty Sky - Realism and Political Theory.' Political Thought and International Relations - Variations on a Realist Theme. Ed. D. Bell. Oxford: Oxford University Press, 2009b: $1-25$

\footnotetext{
${ }^{8}$ For some discussion of these continuities see: Bell 2009a; M.C. Williams 2005; Scheuerman 2013; Sleat 2014; Sleat 2013a. On legal realism see Leiter 2012.

${ }_{9}^{9}$ The authors would like to thank Carlo Argenton, Edward Hall, James Harris, James Hodgson, Luara Ferracioli, Lorna Finlayson, Robert Jubb, Loren King, Janosch Prinz, Andrew Sabl, and Federico Zuolo for their comments on earlier drafts of this paper.
} 
Bellamy, Richard. 'Dirty Hands and Clean Gloves: Liberal Ideals and Real Politics.' European Journal of Political Theory 9.4 (2010):412-430.

Bolsinger, Eckart. The Autonomy of the Political: Carl Schmitt's and Lenin's Political Realism. London: Greenwood Press, 2001.

Bourke, Richard and Geuss, Raymond (eds.). Political Judgement: Essays for John Dunn. Cambridge: Cambridge University Press, 2009.

Carr, E. H. The Twenty Years' Crisis. Basingstoke: Palgrave, 2001.

Chan, Jospeph. 'Legitimacy, Unanimity and Perfectionism.' Philosophy and Public Affairs 29.1 (2000): 5-42.

Ceva, Emanuela, and Enzo Rossi (eds.). Justice, Legitimacy, and Diversity: Political Authority Between Realism and Moralism. London: Routledge, 2012.

Coady, C. A. J. Messy Morality - The Challenge of Politics. Oxford: Oxford University Press, 2008.

Cohen, G.A. Why not Socialism? Princeton, NJ: Princeton University Press, 2009.

Dunn, John. Cunning of Unreason. London: HarperCollins, 2000.

Dunn, J. Interpreting Political Responsibility. Cambridge: Polity Press, 1990.

Dworkin, Ronald. 'Foundations of Liberal Equality.' Tanner Lectures on Human V alues, Vol. 11. Ed. G.B. Peterson. Salt Lake City, UT: University of Utah Press, 1990: 1-119.

Dyson, R.W. Natural Law and Political Realism in the History of Political Thought. Vol. I: From the Sophists to Macbiavelli. Oxford: Peter Lang, 2005.

Erman, Eva, and Niklas Möller. 'Political Legitimacy in the Real Normative World: the Priority of Morality and the Autonomy of the Political.' British Journal of Political Science (2013): DOI: $10.107 /$ S0007123413000148 (Online version of record).

Estlund, David. 'Human Nature and the Limits (if Any) of Political Philosophy.' Philosophy \& Public Affairs 39.3 (2011): 207-37.

Finlayson, Lorna. 2014. “With Radicals Like These....” : Unpublished manuscript, University of Cambridge. URL:

https://www.academia.edu/5916118/_draft_With_radicals_like_these_doom_gloom_and_politi cal_realism. [Accessed 7.2.2014] 
Floyd, Jonathan. and Stears, Marc (eds.). Political Philosophy versus History? Contextualism and Real Politics in Contemporary Political Thought. Cambridge: Cambridge University Press, 2011.

Forrester, Katrina. 'Judith Shklar, Bernard Williams and political realism.' European Journal of Political Theory 11.3 (2012): 247-272.

Freeden, Michael. 'Interpretative Realism and Prescriptive Realism.' Journal of Political Ideologies 17.1 (2012): 1-11.

Galston, William. 2010. 'Realism in Political Theory.' European Journal of Political Theory 9.4 (2010): 385-411.

Geuss, Raymond. 'Realismus, Wunschdenken, Utopie.' Deutsche Zeitschrift für Philosophie 58.3 (2010): 419-429.

Geuss, Raymond. Philosophy and Real Politics. Oxford: Princeton University Press, 2008.

Geuss, Raymond. 'Liberalism and Its Discontents.' Political Theory 30.3 (2002): 320-338.

Gledhill, James. 'Rawls and Realism.' Social Theory and Practice 38.1 (2012): 55-82

Gray, John. Two Faces of Liberalism. New York: New Press, 2000.

Gray, John. Enligbtenment's Wake. London: Routledge, 1995.

Habermas, Jürgen. Between Facts and Norms. Cambridge: Polity Press, 1997.

Hall, Edward. 'Bernard Williams and the Basic Legitimation Demand: A Defence.' Political Studies (2013a): DOI: 10.1111/1467-9248.12070 (Online version of record).

Hall, Edward. 'Political Realism and Fact-Sensitivity.' Res Publica: A Journal of Moral, Legal and Social Pbilosophy 19.2 (2013b): 173-181.

Hawthorn, Geoffrey. Thucydides on Politics: Back to the Present. Cambridge: Cambridge University Press, 2014.

Herz, J. H. Political Realism and Political Idealism - A Study in Theories and Reality. Chicago: Chicago University Press, 1951.

Honig, Bonnie. and Stears, Marc. 'The new realism: From modus vivendi to justice.' Political Philosophy versus History? Contextualism and Real Politics in Contemporary Political Thought. Eds. J. Floyd and M. Stears. Cambridge: Cambridge University Press, 2011: 177-205. 
Horton, John. 'Political Legitimacy, Justice and Consent', Critical Review of International Social and Political Philosophy, 15:2 (2012): 129-148.

Horton, John. 'Realism, liberal moralism and a political theory of modus vivendi.' European Journal of Political Theory 9.4 (2010): 431-48.

Humphrey, Mathew. 'Getting "Real" About Political Ideas: Conceptual Morphology and the Realist Critique of Anglo-American Political Philosophy.' Liberalism as Ideology - Essays in Honour of Michael Freeden. Eds. B. Jackson and M. Stears. Oxford: Oxford University Press, 2012: 241-258.

Hurka, Thomas. 'Review of Raymond Geuss' Philosophy and Real Politics.' Notre Dame Philosophical Reviews (2009): URL: https://ndpr.nd .edu/news/23887-philosophy-and-realpolitics/ [accessed 7.2.2014]

Jubb, Robert. and Rossi, Enzo. 'Political Norms and Moral Values.', Journal of Philosophical Research (forthcoming).

Jubb, Robert. 'Playing Kant at the Court of King Arthur.' Political Studies (forthcoming-a).

Jubb, Robert. "'Recover it from the Facts as we Know Them": Practice-Dependence's Predecessors', Journal of Moral Philosophy (forthcoming-b).

Jubb, Robert and Faik Kurtulmus, A. 'No Country for Honest Men: Political Philosophers and Real Politics.' Political Studies 60.3 (2012): 539-556.

Jubb, Robert. 'Logical and Epistemic Foundationalism about Grounding: The Triviality of Facts and Principles.' Res Publica, 15.4 (2009): 337-353.

Kukathas, Chandran. The Liberal Archipelago. Oxford: Oxford University Press, 2003.

Kukathas, Chandran. 'Justicitis.' (2013): Unpublished manuscript, London School of Economics and Political Science.

Larmore, Charles. 'What is Political Philosophy?' Journal of Moral Philosophy 10 (2013): 276306.

Leiter, Brian. 'In Praise of Realism (And Against “Nonsense” Jurisprudence).' Georgetown Law Journal 100: 865-893.

Maloy, Jason S. Democratic Statecraft: Political Realism and Popular Power. Cambridge: Cambridge University Press, 2013. 
Mantena, Karuna. 'Another Realism: The Politics of Gandhian Nonviolence.' American Political Science Review 106.2 (2012): 455-470.

Mason, Andrew. 'Rawlsian theory and the circumstances of politics.' Political Theory 38.5 (2010): 658-683.

McCabe, David. Modus Vivendi Liberalism. Cambridge: Cambridge University Press, 2010.

Morgenthau, Hans. J. Politics among Nations - The Struggle for Power and Peace, 4th ed. New York: Alfred A. Knopf, 1967.

Morgenthau, Hans. J.. Scientific Man vs. Power Politics. Chicago: Chicago University Press, 1946.

Mouffe, Chantal. The Return of the Political. London: Verso, 2005.

Mulieri, Alessandro. 'L'altro New Realism: anatomia del revival realista anglosassone.' Micromega 16.7 (2013): URL: http://ilrasoiodioccammicromega.blogautore.espresso.repubblica.it/files/2013/07/Mulieri-new-realism.pdf [accessed 1.2.2013]

Newey, Glen. Toleration in Political Conflict. Cambridge: Cambridge University Press, 2013.

Newey, Glen. 'Two Dogmas of Liberalism.' European Journal of Political Theory 9.4 (2010): 449465.

Newey, Glen. After Politics: the Rejection of Politics in Contemporary Liberal Philosophy. Basingstoke: Palgrave, 2001.

Newey, Glen. 'Political Lying: A Defence.' Public Affairs Quarterly. 11.2 (1997): 93-116.

Niebuhr, Reinhold. The Children of Light and the Children of Darkness. London: University of Chicago Press, 2011.

Niebuhr, Reinhold. Moral Man and Immoral Society. London: Continuum, 2005.

Owen, David. 'Die verlorene und die wiedergefundene Wirklichkeit. Ethik, Politik und Imagination bei Raymond Geuss.' Deutsche Zeitschrift für Philosophie 58.3 (2010): 431-443.

Philp, Mark. 'Realism without Illusions.' Political Theory 40.5 (2012): 629-649.

Philp, Mark. 'What is to be Done? Political Theory and Political Realism.' European Journal of Political Theory 9.4 (2010): 466-84. 
Philp, Mark. Political Conduct. London: Harvard University Press, 2007.

Rawls, John. Political Liberalism. New York: Columbia University Press, 1996.

Rawls, John. A Theory of Justice. Oxford: Oxford University Press, 1999.

Raz, Joseph. The Morality of Freedom. Oxford: Clarendon Press, 1986.

Ripstein, Arthur. Force and Freedom. Cambridge, MA: Harvard University Press, 2009.

Rossi, Enzo. 'Facts, Principles, and Politics.' (2014): Working paper available at SSRN. URL: http://papers.ssrn.com/sol3/papers.cfm?abstract_id=2378366

Rossi, Enzo. 'Consensus, Compromise, Justice and Legitimacy.' Critical Review of International Social and Political Philosophy 16.4 (2013): 557-572.

Rossi, Enzo. 'Justice, Legitimacy and (Normative) Authority for Political Realists.' Critical Review of International Social and Political Philosophy 15.2 (2012): 149-164.

Rossi, Enzo. 'Reality and Imagination in Political Theory and Practice: on Raymond Geuss's Realism.' European Journal of Political Theory 9.4 (2010a): 504-512.

Rossi, Enzo. 'Modus Vivendi, Consensus, and (Realist) Liberal Legitimacy.' Public Reason: Journal of Political and Moral Philosophy 2.2 (2010b): 21-39.

Runciman, David. 'What Is Realistic Political Philosophy?' Metaphilosophy 43.1-2 (2012): 5870.

Sabl, Andrew. Hume's Politics. Oxford: Princeton University Press, 2012.

Sabl, Andrew. Ruling Passions: Political Offices and Democratic Ethics. Oxford: Princeton University Press, 2008.

Scheuerman, W. E. 'The realist revival in political philosophy, or: Why new is not always improved.' International Politics 50.6 (2013): 798-814.

Schlosser, Joel Alden. 'Hereodotean Realism.' Political Theory (forthcoming): DOI: 10.1177/0090591713516472 (Online version of record).

Schwartzman, Lisa H. 'Abstraction, Idealization, and Oppression.' Metaphilosophy 37.5 (2006): 565-588. 
Shklar, Judith. N. 'The Liberalism of Fear.' Judith N. Shklar - Political Thought and Political Thinkers. Ed. S. Hoffman. London: University of Chicago Press, 1998. 3-20.

Sigwart, Hans-Jörg. 'The Logic of Legitimacy: Ethics in Political Realism.' The Review of Politics 75 (2013): 407-432.

Sleat, Matt. 'Legitimacy in Realist Thought: Between Realism and Realpolitik.' Political Theory (2014): DOI: 10.1177/0090591714522250 (Online version of record).

Sleat, Matt. Liberal Realism: A Realist Theory of Liberal Politics. Manchester: Manchester University Press, 2013a.

Sleat, Matt. 'Hope and Disappointment in Politics.' Contemporary Politics 19.2 (2013b): 131 145.

Sleat, Matt. 'Legitimacy in a Non-Ideal Key: a Critical Response to Andrew Mason.' Political Theory 40.5 (2012): 650-656.

Sleat, Matt. 'Liberal Realism: A Liberal Response to the Realist Critique.' The Review of Politics, 73.3 (2011): 469-496.

Sleat, Matt. 'Bernard Williams and the Possibility of a Realist Political Theory.' European Journal of Political Theory 9.4 (2010): 485-503.

Stears, Marc. 'Liberalism and the Politics of Compulsion.' British Journal of Political Science 37 (2007): 533-553.

Taylor, Craig. Moralism: A Study of a Vice. Durham: Acumen, 2011.

Valentini, Laura. 'Ideal vs. Non-Ideal Theory: a Conceptual Map.' Philosophy Compass 7.9 (2012): 654-64.

Waldron, Jeremy. 'Political Political Theory: An Inaugural Lecture.' Journal of Political Philosophy 21.1 (2013): 1-23

Waldron, Jeremy. Law and Disagreement. Oxford: Oxford University Press, 1999.

Walz, Kenneth. Theory of International Politics. USA: Waveland Press, 2010.

Weber, Max. 'The Profession and Vocation of Politics.' Weber - Political Writings. Eds. P. Lassman and R. Speirs. Cambridge: Cambridge University Press, 1994: 309-69. 
Whelan, Francis. G. Hume and Machiavelli: Political Realism and Liberal Thought. USA: Lexington Books, 2004

Williams, Bernard. In the Beginning was the Deed. Ed. G. Hawthorn. Oxford: Princeton University Press, 2005.

Williams, Bernard. Truth and Truthfulness. Princeton, NJ: Princeton University Press, 2002.

Williams, Michael. C. The Realist Tradition and the Limits of International Relations. Cambridge: Cambridge University Press, 2005.

Zuolo, F. 'Realism and Idealism.' Handbook of Political Philosophy. Ed. A. Besussi. Aldershot: Ashgate, 2012: 65-75. 